\title{
Evaluation of Tourism Potential Development Policy in Togean Islands, Tojo Una Una Regency
}

\author{
Indrawijaya $^{1}$, Alam Anshary ${ }^{1}$, Hasanuddin Mustari ${ }^{1}$, Muhammad Khairil ${ }^{1}$ \\ indrawijayatadulako@gmail.com \\ ${ }^{1}$ Faculty of Social Science and Political Science,Universitas Tadulako, Indonesia
}

\begin{abstract}
The purpose of this study was to determine the extent to which the development of tourism potential based on the aspects of tourism attraction and promotion, human resources and institutions, the environment, as well as aspects of tourism accessibility and facilities. This study uses a qualitative method with a phenomenological approach to describe, analyze and interpret the implementation of programs / activities from various aspects of tourism development. The theory used in this research is William Dunn's policy evaluation theory with the criteria of effectiveness, efficiency, sufficiency, leveling, responsiveness, and accuracy. Research result shows the development of tourism attractions and promotion is not in line with the concept of sustainable development and the image of the Togean Islands as a new ecotourism destination. The development of community empowerment, research and education on ecosystems, as well as improving the human resources of tourism actors have not run optimally in accordance with the potential of natural tourism. Programs / activities for the protection, supervision and management of priority tourist destinations, especially those that have the appeal of snorkeling and diving, have not been implemented optimally so that illegal fishing activities and waste problems cannot be resolved properly. The priority of developing transportation access for tourists is not appropriate and uneven in order to respond to the needs of tourist visits to priority tourist destinations.
\end{abstract}

Keywords: Evaluation, Tourism Policy, Responsiveness, Accuracy

Received: November 4, 2020

Received in Revised: November 14, 2020

Accepted: November 23, 2020

\section{Introduction}

National development is carried out evenly throughout the country so that it is not only felt by one group or part of the community, but must actually be enjoyed by all the people as part of improving the level of life with social justice, which is the goal and ideals of Indonesian independence. To implement a policy, the National Development is implemented evenly throughout the country, both at the center and in the village area (Turambi \& Rende, 2016). Including tourism sector development policies. In the current era of globalization, the tourism sector is the largest and strongest industry in financing the global economy. The tourism sector will be the main driver of the world economy and become one of the global industries. The tourism industry is one of the right ways to increase the economic progress of the community, both locally and globally. There are four main areas that are influenced by tourism development efforts, namely economy, social and culture and the environment (Yustati et al., 2018).

In government regulations it is stated that tourism is a variety of tourist activities and is supported by various facilities and services provided by the community, businessmen, government and local governments (Hendrita, 2017). Tourism activities have many types of both artificial tourism and natural tourism, in nature tourism there are several forms of tourism activities, one of these natural tourism activities is coastal tourism activities, coastal 
tourism activities are recreational activities carried out around the coast such as swimming, surfing, sunbathing, diving, snorkeling, strolling or running along the beach, enjoying the beauty of the coastal atmosphere, and meditating (Tatali et al., 2018). The Government and Regional Governments, the tourism business world, and the community are obliged to ensure that travel as the right of everyone can be upheld so as to support the achievement of increased human dignity, increased welfare, and friendship between nations in the context of realizing world peace (Prihartono et al., 2017).

One of the things needed to support this is a good organizational environment. Organizations that have clear division of tasks, hierarchies and lines of authority are good types of bureaucratic structures. Such a bureaucratic posture clearly has a line of authority for structural officials in taking steps to carry out disciplinary guidance in accordance with the authorities and responsibilities they have and the work unit they lead (Pasinringi et al., 2020). Included in it is the involvement of community participation, participation can be defined as the mental / thought and emotional / emotional involvement of an individual in a community environment, in an effort to achieve its goals (Tjaija et al., 2020).

The country of Indonesia as we know it is one of the developing countries that has various kinds of tourism potential, both natural tourism and cultural tourism because Indonesia has various ethnic groups, customs, and cultures and because of the geographical location of Indonesia as a tropical country that produces natural beauty and beauty. animals (Primadany, 2013), The tourism sector with the most potential and prioritized development is the potential for marine tourism and cultural tourism including local wisdom which is the soul of existing cultural diversity (Tamaratika \& Rosyidie, 2017).

In line with the national tourism development policy and by taking into account the potential tourist attractions that are owned, the tourism sector in Central Sulawesi, especially Tojo Una-Una Regency, Togean Islands has received great attention from the Regional Government to become one of the leading tourist destinations that have the power tourist attraction as regulated in PP. 50 of 2011 concerning the National Tourism Development Master Plan (RIPPARNAS) 2010-2025, stipulates that the Togean Islands are included in the 50 national tourism destinations (Badarab et al., 2017), The tourism potential in the Togean Islands conservation area is not only in biological resources, but also in geological resources (Botjing \& Asrafil, 2019). Therefore, it is necessary to evaluate tourism development policies in Tojo Una Una Regency.

In general, Winarno said that evaluation can be said to be an activity that involves estimating or assessing policies that cover substance, implementation and impact (Haryanti \& Sari, 2017). Meanwhile, Wirawan said that evaluation is a research to collect, analyze, and present useful information about the object of evaluation, evaluate it and compare it with evaluation indicators and the results are used to make decisions about the object of evaluation (Divayana \& Sugiharni, 2016). Evaluation allows the implementation of a program to find out what results are actually being achieved. An objective, rational assessment and based on the criteria predetermined in the plan will determine whether the results achieved exceed the predetermined targets and standards, the results achieved are just as expected, or less than what is determined (Valdiano \& Mudjito, 2019). In this study, the theory used is the theory of policy evaluation according to William Dunn, namely effectiveness, adequacy, equity, responsiveness and accuracy. (Widiastuti \& Santoso, 2017).

\section{Methods}

This type of research uses a descriptive method with a qualitative approach (Rachman, 2017), This study uses a qualitative approach with various phenomenologies (Samad et al., 2020), 
The type of data collected in this study is qualitative data, namely data in the form of information or information obtained from informants about internal and external factors as obstacles and supporters (Pantiyasa, 2020).

The research focus is on various tourism events carried out by the government in an effort to attract tourists, in order to introduce the wealth of tourism potential that the Togean Islands, Tojo Una Una Regency, such as the Lipuku charm event.

\section{Results and Discussion}

\section{Tourism Attraction and Promotion}

Tourism Objects and Attractions (ODTW) are the main drivers of the tourism sector. The development of a tourist attraction that presents an attraction for tourists requires the cooperation of all stakeholders consisting of the community and government, direct cooperation from business circles and from the private sector. In accordance with its duties and authorities, the government is the facilitator who has a role and function in making and determining all policies related to the development of tourist objects and attractions.

Attractiveness in tourist objects is one of the main assets that must be owned in an effort to increase and develop tourist destinations. The existence of a tourist attraction is the most important link in a tourist activity, this is because the main factor that makes visitors or tourists come to visit tourist destinations is the potential and attractiveness of these tourism objects.

Togean Islands is one of the tourist destinations in Tojo Una-Una Regency, Sulawesi Province and is one of 50 national tourism destinations. The beauty of tourism in the Togean Islands is a beautiful gaze for every eye that sees it, from the cluster of dozens of islands, the beauty of the beach, the beauty of the enchanting underwater park, historical heritage, local wisdom, and increased knowledge of the ecosystem.

Visiting the Togean Islands allows every tourist to enjoy the beautiful natural beauty and relax the fatigue generated by routine work. The tourism potential of the Togean Islands is a gift from God to the Tojo Una-Una Regency Government and all its people, so it is mandatory for every community to protect and maintain with gratitude and pride for the gift. The Tojo Una-Una Regency Government as the holder of full authority over the tourism management system must act quickly and precisely in the context of development and development so that it can carry out the functions of the community's welfare by utilizing its potential.

The aspects of tourism development that must be carried out in order to realize the development of potential tourist destinations in accordance with the wishes of the community and being able to realize the great Tojo Una-Una in the tourism sector are greatly influenced by the implementation of programs carried out by local governments, especially the Tourism Office. The programs / activities carried out must be able to meet the needs of the tourist market and create independence through community empowerment.

The development of tourism potential can be started by setting priority potentials as development targets. Determining the potential of tourism as a leading tourist destination can be through the policy of a Regent Regulation or a Regulation of the Head of Service. The facts that have occurred in the development of tourism in the Togean Islands, the Tourism Office has not issued a Regional Regulation or a Regent Regulation, even a Head of Service Regulation on priority tourism destinations for Tojo Una-Una Regency especially for Togean Islands destinations so that the development of tourism potential has not been optimal. According to Agus Suryono, the objectives of public policies are related to people's welfare. 
These policy objectives have not been implemented properly, in order to respond to the needs of the community so that the effectiveness and efficiency of tourism development can run according to the objectives to be achieved. Some of the policy objectives are anticipating, reducing, or overcoming social problems that occur in society and fulfilling the needs of individuals, families, groups or communities that they cannot fulfill individually but through collective action (Suryono, 2014).

The priority tourism destinations in Tojo Una-Una Regency, which do not yet have a policy basis in the form of a Regent Regulation, have made several priority destinations in the Togean Islands untouched by development development by the Regional Government. Community empowerment through its tourism potential has not been able to anticipate, reduce and overcome social problems in society, especially poverty. In fact, Tojo Una-Una Regency with its tourism potential still records the first position with the poverty rate in Central Sulawesi Province, this proves that tourism is not capable of being the main driver in dealing with poverty problems.

Central Sulawesi Province Determination of Priority Tourism Destinations (DPP) through Governor Regulation No. 35 of 2016 against eight destinations in the Togean Islands which were deemed inaccurate so that the development program could not run effectively. The development of tourism development in the Togean Islands leads to a special interest attraction with the concept of ecoturism as a sustainable tourism development.

Purnomo's research states that special interest tourism is a form of tour, in which tourists travel or visit a place because they have a special interest or motivation regarding a type of object that can be found at a tourist location (Widhiarini et al., 2019). The results show that the Togean Islands are tourist destinations that offer special interest such as snorkeling and diving as well as education and research on ecosystem observation.

Destinations that are designated as development priorities such as Kaidiri Island and Pangempa Island are not appropriate because these locations have been managed by the private sector to become resorts, making it difficult for the Provincial Government and Regional Governments to develop and construct tourism supporting facilities and infrastructure. Local governments should set priority destinations at snorkeling and diving points that are of special interest to tourists, and set the area around the destination as a priority for developing tourism areas to support the availability of tourism facilities.

Government Regulation Number 50 of 2011 contains a vision of national tourism development, namely the realization of Indonesia as a world-class tourism destination, competitive, sustainable and capable of encouraging regional development and the welfare of the people. In order to realize this vision, 4 (four) tourism development strategies were adopted, which include tourism destinations that are safe, comfortable, attractive and easily accessible; tourism marketing that is synergistic, superior and responsible; a competitive tourism industry; and government, local government, private sector and community organizations that are effective in promoting the realization of sustainable tourism development.

Ecotourism-based development is one of the strategies for advancing regional tourism based on local wisdom. Julian Clifton \& Angela Benson suggest much has been written about the definition of ecotourism, since the concept's popularity in the late 1980s. reference to the need to conserve the environment, provide economic opportunities for local communities, avoid adverse socio-cultural impacts through the presence of visitors to tourist destinations, educational experiences for visitors, or a combination of all these elements (Clifton \& Benson, 2006). 
In an effort to meet the needs of individuals, families, groups or communities that they cannot fulfill individually but must go through collective action in accordance with policy objectives in the context of the welfare of society. The development and development of tourist destinations must be able to respond to the needs of the surrounding community so that with the development of tourist destinations the community gets benefits as a form of effort in improving the community's economy itself.

Development as a destination for developing tourist destinations has not been based on a good destination management system. The development of ecotourism-based destinations is one strategy that can attract foreign tourists to visit. Sustainable Tourism is characterized by focusing on the preservation of the natural and cultural heritage and traditions of local communities by reducing the intensive context and mass. Especially for natural and cultural tourism objects, reducing the negative impacts caused in relation to tourism development, and empowering local communities to increase the degree and social and cultural life in order to improve the quality and standard of living of local communities (Widowati et al., 2019).

Destination development has become less effective due to the analysis of the tourist market that has not been running optimally and is not in accordance with national tourist policies so that tourist destinations are crowned as international standard tourist destinations that can be implemented according to sustainable development goals, the fact is that the development of one of Papan Island destinations is one of the destinations for international standards are currently more in demand by domestic tourists and local tourists.

In this case the Regional Government through the Tourism Office must immediately conduct a study of the tourist market analysis so that the development carried out is in accordance with the objectives of the tourist market and makes it easier to find tourism promotion strategies. The construction of attractiveness becomes inefficient when the concept of developing a tourism attraction focuses more on physical development activities. Activities towards developing ecosystem research and conservation activities are still lacking so that information that can attract tourists to tourists does not run optimally.

Minimal investment in tourism makes regional financial expenditures even greater, the development of investment in the construction of home stays, hotels, travel agents or travel agents can encourage the creation of new business fields, absorb labor so that it can encourage an increase in PAD and reduce poverty through the tourism sector. In carrying out efficient and effective tourism development the Tourism Office must be able to take advantage of the potential that the village has, including the Village Fund budget which can be used to carry out development and community empowerment.

Based on the 2019 village ministry regulation, tourism development and development can take advantage of the Village Fund budget. Seeing that a conducive tourism climate can be created by building and providing village infrastructure needs so that they can contribute to increasing the potential of the village, as well as as a village asset in order to accelerate the development of tourist destinations in the village. The basic concept of a homestay is a tourist attraction (elevating traditional archipelago architecture and interaction with local communities) and amenities (a safe, comfortable and international standard place to live).

The purpose of using the Village Fund based on Permendes No.11 of 2019 to finance the development of a Tourism Village are to improve the Village economy, creating jobs in the village, lifting the culture, uniqueness, authenticity and characteristic of the local village, encourage the development of local entrepreneurship, and encouraging an increase in Village Original Income (PAD) through village-owned enterprises (BUMDES). 
The types of tourism village development activities that can be financed from the Village Fund and subsequently managed by village-owned enterprises (BUMDesa) based on Permendes No.11 of 2019 include: national / international standard homestays, toilets / MCK with national / international standards, souvenir stalls, changing rooms and / or toilets, Pergola, Gazebo, Garden lights, Guardrails, arts / performances stages, culinary hawker centers, places of worship, viewing decks, identity gates, children's games , Outbound game rides, recreational parks, ticket sales points, tourist transportation, mangrove tourism tracking, snorkeling and diving tourism equipment, interpretation boards, cleaning facilities and infrastructure, making promotional media (brochures, leaflets, audio visuals), internet corners, training guides Tourism, Tourism interpretation, Tourism Village management training, Tourism awareness training and formation of tourism awareness groups / Pokdarwis, and Pengem development of conversion schemes and renovation of traditional houses, etc.

The development of the development of good and right-on-target tourism destinations will become materials for tourism promotion activities, the tourism promotion carried out will be in accordance with the attractiveness and tourist attractions offered so that it will hypnotize potential tourists to visit the Togean Islands. The implementation of tourism promotion must be in accordance with the facts and realities in the field, otherwise the disappointment of visiting tourists will have an impact on not re-visits and the Togean Islands will get a negative assessment for tourists.

One of the promotional activities that is routinely carried out is the Pesona Lipuku activity, since 2017 the lipuku charm activity has been lauching into the annual activity agenda even in 2018 the Pesona Lipuku Festival is included in the "top 100 wonderful Indonesian event" promotional activities that use a lot of budget are one a flagship program which is expected to increase tourist visits in the following years and encourage an increase in the community's economy.

According to the Head of the Tojo Una-Una Regency Tourism Office, Mr. Mario Dg Pawadjoi, "The Enchantment Festival of Lipuku will introduce tourists to the beauty of six islands from 40 major islands in Togean. Places such as Kadidiri Island, Pangempa, Bolilanga, Taupan Island, Jellyfish Lake and Kulingkinari are ready to be explored. "As part of the world's coral triangle apart from the Philippines and Papua New Guinea, the Togean Islands have one of the most beautiful underwater landscapes in Indonesia with coral reefs. very healthy and natural.

The lipuku charm festival which is held is inversely proportional and not in accordance with the marketing strategy of how not the Regional Original Income (PAD) decreased in 2018 and the number of visits that decreased considerably in 2019 is a real fact and makes the Lipuku charm promotion activities not have a good impact for an increase in Regional Original Revenue (PAD) and an increase in the number of tourist visits in accordance with what has been planned by the Regional Government of Tojo Una-Una Regency.

Organizing tourism promotion events has become less effective because promotional activities that have spent a large enough budget on the implementation of Pesona Lipuku have not been able to lift the image of the Togean Islands. The concept offered through promotional activities does not touch the attractiveness offered by the Togean Islands, based on the results of previous observations and research on the activities of tourists visiting the Togean Islands as a special attraction for snorkeling, diving, sun banthing and island hopping for local tourists.

Promotions that are carried out are ineffective because promotional activities do not focus on how tourists can carry out vacation activities in accordance with the renewable attractions 
offered by the Togean Islands. The promotional activities carried out have not yet presented an impression that is able to hypnotize more potential tourists to visit the Togean Islands.

The second promotional activity carried out in 2018 using a large enough budget was the implementation of the TIOF (Togean International Ocean Festival). The implementation of TIOF aims to attract foreign tourists to visit the Togean Islands which in turn will have an impact on improving the community's economy. This international tourism promotion activity has a concept of performing music over the sea using a floating stage. Not only a floating stage, but the audience can also enjoy the music performed by boat.

This activity is quite attractive for visitors to the Togean Islands, according to the estimated target that around 3,000 (three thousand) tourists will arrive. The number of visits in these promotional activities is less efficient because it uses a budget of approximately 3 billion Rupiah and the implementation time is not quite right so that it brings in more local tourists and even tourists from Tojo Una-Una Regency and invited guests of the Regional Government, so that what becomes activity objectives become inefficient and ineffective. Tourism activities should be able to bring in activities that can bring in tourists not only in the implementation of promotional activities but can bring in tourists in the following years so that a sustainable tourism program can be realized.

The Togean Islands, which are known for their beautiful and unspoiled underwater beauty, motivate foreign tourists to come and visit in order to enjoy the underwater beauty, the promotional programs / activities carried out must lead to tourist destinations, so that tourism development can run according to what is expected. has been planned and in accordance with the concept of national development in the tourism sector. The concept of activities that are inaccurate and do not respond to the wishes of the tourist market means that the programs / activities carried out by the Pariwiata Office do not lead to the sustainability aspect.

Based on the Sustainability Aspects written by Ni Made, Putu Eni and Ni Putu in a journal entitled "Traditional Balinese Architecture in Puris Buildings as a Special Interest Tourist Attraction in Supporting Sustainable Tourism Development in Bali (Widhiarini et al., 2019), Some of the opinions of Thalia experts state that the shift in tourism interest from the concept of artificial tourism to natural tourism gave birth to the development of sustainable tourism through the development of special interest tourism (Widhiarini et al., 2019). Special interest tourism is a tourism pattern that emphasizes a greater appreciation and appreciation for the preservation of nature, environment, and culture (environmental and cultural sensitives).

This is in line with the United Nation's World Tourism Organization program, where tourism development must pay attention to aspects of sustainability, namely the existence of a balance between economy, socio-culture and the environment. Based on this, Indonesia's natural wealth and cultural diversity have great potential in supporting the sustainable development of special interest tourism. Special interest tourism is a form of activity with individual tourists, groups or small groups whose purpose is to learn and try to gain experience in the area being visited (Fandeli, 2002).

In order to promote tourist destinations in the Togean Islands, the tourism office can collaborate with several electronic media, especially social media, to help promote more effective and efficient promotional activities. Currently, social media plays a role in promoting and also spending less than conducting promotional activities with the concept of inviting people to come to attend ceremonial and unsustainable activities. The Tourism Office through the promotion sector can also carry out promotional activities by visiting universities in several regions to explain tourism potential as well as collaborating in the field of community service and research that can be done in the Togean Islands. 


\section{Conclusion}

Based on the results of the analysis described above, it is necessary to put forward a minor proposition from the evaluation of the four aspects of tourism development that have been carried out, namely first, if the development of the attraction focuses on activities to increase attractions in tourist destinations, it will attract the attention of potential tourists to visit the Togean Islands. Furthermore, if tourist attraction is packaged with the concept of innovative promotional activities and is able to adapt to the desires of the tourist market, there will be an increase in visits so that effective tourism potential development policies will be fulfilled. Second, if the human resource aspect is developed based on standardized quality improvement priorities accompanied by optimization of tourism support institutions, it will give birth to professional tourism management so that efficiency in developing tourism potential in the Togean Islands will be fulfilled. Third, if the environmental development aspects are prioritized through natural resource conservation programs, community empowerment and environmental research and development, then tourist destinations will run right on target in accordance with the concept of sustainable tourism and the image of the Togean Islands as a new ecoturism destination in accordance with the direction of central government policies. Fourth, if the accessibility of supporting tourism is built based on the target market goals of tourists, the comfort of tourists will be fulfilled, the comfort of tourists, if supported by standardization of tourism support facilities, will create security in traveling.

\section{References}

Badarab, F., Trihayuningtyas, E., \& Suryadana, M. L. (2017). Strategi Pengembangan Destinasi Pariwisata di Kepulauan Togean Provinsi Sulawesi Tengah. THE Journal : Tourism and Hospitality Essentials Journal, 7(2), 97-112. https://doi.org/10.17509/thej.v7i2.9016

Botjing, M. U., \& Asrafil. (2019). Inventarisasi Situs-Situs Geologi Sebagai Potensi Geowisata Di Kepulauan Togean, Provinsi Sulawesi Tengah. Bomba: Jurnal Pembangunan Daerah, 1(2), 43-48.

Clifton, J., \& Benson, A. (2006). Planning for Sustainable Ecotourism: The Case for Research Ecotourism in Developing Country Destinations. Journal of Sustainable Tourism, 14(3), 238-254. https://doi.org/10.1080/09669580608669057

Divayana, D. G. H., \& Sugiharni, G. A. D. (2016). Evaluasi Program Sertifikasi Komputer Pada Universitas Teknologi Indonesia Menggunakan Model CSE-UCLA. JPI (Jurnal Pendidikan Indonesia), 5(2), 158-165. https://doi.org/10.23887/jpiundiksha.v5i2.8586

Fandeli, C. (2002). Pengembangan Kawasan Pedesaan Sebagai Objek Wisata (Identifikasi Potensi dan Perencanaan Model Pariwisata Pedesaan Sekitar Gunung Merapi Yogyakarta ) [Lembaga Penelitian]. https://repository.ugm.ac.id/digitasi/index.php?module=cari_hasil_full\&idbuku=214

Haryanti, R. H., \& Sari, C. (2017). Aksesibilitas Pariwisata Bagi Difabel di Kota Surakarta (Studi Evaluasi Peraturan Menteri Pekerjaan Umum Nomor 30 Tahun 2006 Tentang Pedoman Teknis Fasilitas Dan Aksesibilitas Pada Bangunan Gedung Dan Lingkungan). Spirit Publik: Jurnal Administrasi Publik, 12(1), 85-96. https://doi.org/10.2096/sp.v12i1.11748

Hendrita, V. (2017). Kebijakan Pengembangan Pariwisata di Kabupaten Tanah Datar. Agrifo: Jurnal Agribisnis Universitas Malikussaleh, 2(2), 73-82. https://doi.org/10.29103/ag.v2i2.379 
Pantiyasa, I. W. (2020). Evaluasi Pengelolaan Desa Wisata Kaba-Kaba, Kecamatan Kediri Kabupaten Tabanan. Jurnal Ilmiah Hospitality Management, 10(2), 109-129. https://doi.org/10.22334/jihm.v10i2.165

Pasinringi, A., Alamsyah, M. N., \& Samad, M. A. (2020). Measuring the Level of Discipline of Bureaucrats in Palu City. International Journal of Multicultural and Multireligious $\quad$ Understanding, $7(10), \quad 79-86$. https://doi.org/10.18415/ijmmu.v7i10.2011

Prihartono, A., Muin, F., \& Mucharom, R. S. (2017). Orientasi Pariwisata dan Local Wisdom di Prov. Banten Dalam Kerangka Otonomi Daerah | Prosiding CELSciTech. http://ejurnal.umri.ac.id/index.php/PCST/article/view/342

Primadany, S. R. (2013). Analisis Strategi Pengembangan Pariwisata Daerah (Studi pada Dinas Kebudayaan dan Pariwisata Daerah Kabupaten Nganjuk). Jurnal Administrasi Publik, 1(4), 135-143.

Rachman, L. F. (2017). Evaluasi Kebijakan Pengembangan Kasawasan Agropolitan di Desa Mayanggeneng Kecamatan Kalitidu Kabupaten Bojonegoro. Publika, 5(4), Article 4. https://jurnalmahasiswa.unesa.ac.id/index.php/publika/article/view/20688

Samad, A., Erdiansyah, E., \& Wulandari, R. (2020). Evaluasi Kebijakan Pemerintah Pasca Bencana (Studi Kasus Bencana di Sulawesi Tengah). Publik (Jurnal Ilmu Administrasi), 9(1), 15-24. https://doi.org/10.31314/pjia.9.1.15-24.2020

Suryono, A. (2014). Kebijakan Publik untuk Kesejahteraan Rakyat | Suryono | Transparansi: Jurnal Ilmiah Ilmu Administrasi. Transparansi: Jurnal Ilmiah Ilmu Administrasi. http://ojs.stiami.ac.id/index.php/transparansi/article/view/33

Tamaratika, F., \& Rosyidie, A. (2017). Inkorporasi Kearifan Lokal Dalam Pengembangan Kawasan Pariwisata di Lingkungan Pantai. Jurnal Sosioteknologi, 16(1), 125-133. https://doi.org/10.5614/sostek.itbj.2017.16.1.10

Tatali, A. A., Lasabuda, R., Andaki, J. A., \& Lagarense, B. E. S. (2018). Strategi Pengembangan Pariwisata Pesisir di Desa Bentung Kabupaten Kepulauan Sangihe Provinsi Sulawesi Utara. Jurnal Kebijakan Sosial Ekonomi Kelautan dan Perikanan, 8(1), 53-62. https://doi.org/10.15578/jksekp.v8i1.6703

Tjaija, A., Samad, M. A., \& Putra, R. E. (2020). Technocratic Development Planning Policies. International Journal Papier Public Review, 1(2), 12-20. https://doi.org/10.47667/ijppr.v1i2.19

Turambi, J. M., \& Rende, D. C. (2016). Pengaruh Pembangunan Terhadap Stratifikasi Sosial Masyarakat di Kelurahan Buyungon Kecamatan Amurang. Journal Social Welfare, 4(1), Article 1. http://www.jurnal.stiksmanado.ac.id/index.php/welfare/article/view/7

Valdiano, V., \& Mudjito. (2019). Evaluasi Prosedur Kerja Organisasi di Sekolah Tinggi Teknologi Angkatan Laut. Inspirasi Manajemen Pendidikan, 7(1), Article 1. https://jurnalmahasiswa.unesa.ac.id/index.php/inspirasi-manajemenpendidikan/article/view/29155

Widhiarini, N. M. A. N., Oktavian, P. E., \& Permanita, N. P. F. D. (2019). Arsitektur Tradisional Bali Pada Bangunan Puri Sebagai Daya Tarik Wisata Minat Khusus Dalam Mendukung Pengembangan Pariwisata Berkelanjutan di Bali. Pusaka: Journal of Tourism, Hospitality, Travel and Business Event, 1(2), 46-52. https://doi.org/10.33649/pusaka.v1i2.18 
Widiastuti, D., \& Santoso, R. S. (2017). Evaluasi Kebijakan Peraturan Walikota Semarang N0. 05 Tahun 2013 Tentang Penataan Toko Modern Minimarket Kota Semarang (Studi di Kecamatan Banyumanik Kota Semarang). Journal of Public Policy and Management Review, 6(2), 876-892-892. https://doi.org/10.14710/jppmr.v6i2.16226

Widowati, S., Ginaya, G., \& Triyuni, N. N. (2019). Penta helix model to develop ecotourism: Empowering the community for economic and ecological sustainability. International Journal of Social Sciences and Humanities, 3(2), 31-46. https://doi.org/10.29332/ijssh.v3n2.288

Yustati, H., Auditya, L., Indra, Y. A., Fryanti, Y. E., \& Stiawan, E. (2018). Religious Commodification to Increase Public Welfare Through Tourism Halal in Indonesia. Proceeding IAIN Batusangkar, 1(1), 209-216. 